\title{
Local community perception toward the incentive system in the sustainable tourism quality development at Linow Lake, North Sulawesi
}

\author{
Ronald Yusak Boka ${ }^{1}$, Maryunani ${ }^{2}$, Wiske Rotinsulu ${ }^{3}$ and Luchman Hakim ${ }^{4}$ \\ (I) Graduate Scholl of Science and Environmental Technology, Brawijaya University, Jl. Veteran Malang, \\ 65145, East Java, Indonesia and Department of Industrial Engineering, Minaesa Institute of Technology, \\ Tomohon North Sulawesi \\ ${ }^{(2)}$ Faculty of Economics, Brawijaya University, Jl. Veteran Malang, 65145, East Java, Indonesia \\ ${ }^{(3)}$ Department of Agronomy, Faculty of Agriculture, Sam Ratulangi University, Manado North Sulawesi, \\ Indonesia \\ ${ }^{(4)}$ Department of Biology, Faculty of Science and Graduate Scholl of Science and Environmental Technology, \\ Brawijaya University, Jl. Veteran Malang, 65145, East Java, Indonesia
}

\begin{abstract}
This study aims at examining the perception of local community toward the incentive system which was applied in the tourism industry in Linow Lake. The results of the study show that Linow Lake is a natural tourism object which is potential to be developed to support local government revenue and local community welfare. Linow Lake is a geological phenomenon having high natural resources and biodiversity thus; its development needs to consider the nature preservation aspects. The local government has developed an incentive system in order to accelerate sustainable tourism at Linow Lake. However, local community feels that the system does not run well. The local people think that non-physical aspects, such as management, need to be improved more professionally. In addition, intensive training and education related to the management of tourism objects, like Linow Lake, is indispensable.
\end{abstract}

Keywords: conservation, incentive system, lake conservation, tourism development

\section{INTRODUCTION}

Tourism is one of the promising sectors which can help to improve national revenue and foreign exchange, to improve the quality of the environment, and to promote cultural and natural potentials of the country to the world. UNWTO records that tourism is one of the economy boosters in many countries and regions around the world. Asia Pacific is predicted to experience rapid tourism growth and development. Asia Pacific is naturally and culturally rich; it is a zone with such high biodiversity and multi-ethnic habitants having attractive culture and beautiful nature[1].

Indonesia is one of the famous tourism destinations in the world for its various culture and natural resources [2]. In Indonesia, tourism development gains serious attention from both local and national governments [3]. The government of Indonesia believes that tourism sector plays such important role in the development of local regions and acts as a catalyst in the development and advancement of other sectors. Tourism can open up employment for local communities [4] [5]. Tourism development in many parts of the world is always supported with such comprehensive policy instruments, especially in the optimization of economic profits with yet high consideration on nature and local culture preservation [6].

A set of regulations established by the government to direct development programs that support nature protection has become an incentive system which is quite effective to support nature preservation. In Indonesia, the incentive system can be found in Indonesian Law Number 24 of 1992 (about Spatial Planning Regulations) which explains that an incentive systems is a set of rules aims at giving stimulus toward Green Open Space establishment. On the other hand, regulations aim at limiting the number of activities to preserve the Green Open Space is called as disincentive [7].

In the context of sustainable development, the proportion of incentive and disincentive must be made in such ways that the development of tourism can stimulate the preservation of balanced ecology, yet it does not counterproductive toward sustainable development programs [6]. According to Law No. 24 of 1992, there are two forms of incentives, namely economy incentive and physical incentive. Economy incentive is always related to the giving of compensation and reward. Physic incentive can come in form of infrastructure and facilities [7]. To support the development of tourism, it is common for government to build infrastructure and facilities [4] [8] [9].

In developing countries, the success of local incentive system in the development of tourism is rarely studied, and it becomes one of the main weaknesses in the planning and development of local tourism. Criticism 
is mostly directed toward the gaps of policy and reality. This study aims at examining the local community perception toward the incentive system in the sustainable tourism quality program at Linow Lake. Tomohon, a town located in North Sulawesi, is chosen as a study site since this town is aggressively developing its tourism to support the program of North Sulawesi Province that is making this province as one of the world tourism destinations.

\section{RESEARCH MethODS}

\section{Study site}

The study takes place in Linow Lake, Tomohon, in North Sulawesi. Tomohon is located in mountainous area with such cool climate and extraordinary mountainous scenery. Geographically, Tomohon is located $\pm 700 \mathrm{~m}$ asl surrounded by three mountains namely Lokon Mountain (1,689 $\mathrm{m}$ asl), Mahawu Mountain $(1,311 \mathrm{~m}$ asl $)$ and Masarang Mountain $(560 \mathrm{~m}$ asl). Lokon Mountain is one of the most active volcanoes in North Sulawesi, last erupted in 2012. The volcanic effect of these three mountains lead Tomohon area as fertile areas that good for farming activities.

Linow Lake is one of the natural wealth which is potential to be developed into a tourism attraction in Tomohon. Linow Lake is a volcanic lake with the width of 34 hectares which is still showing some signs of geological phenomenon in form of sulfur craters. The sulfur content causes the water to always change colors. The beauty of Linow Lake has long attracted tourists to come. Administratively, the lake is located in Lahendong Village, South Tomohon District, Tomohon Regency, North Sulawesi Province. It is very easy to get into the lake. It is located $4 \mathrm{~km}$ from the town center and it can be reach by public transportation from Tomohon bus station for only IDR 2,000 per person. The fee to enter the lake is IDR 25,000 per person

\section{Research procedures}

The study was conducted from October 2012 until March 2013 in Lahendong Village. The study was done in three main stages, namely understanding the documents on development policy of Tomohon, distributing questionnaires to respondents, and descriptive gap analyses.

Study on policy documents was done by reading the documents of Tomohon government on tourism development. The official documents such as Medium-Term Development Plan, Government Work Plan Year 2011, 2012, and 2013, and other documents were analyzed. Incentives policy which was written on the documents was recorded for further analyses.

Field observations were done by visiting the lake regularly. The basic bio-geo-physic characteristics, as well as the quality of facilities and infrastructure around the lake were observed and recorded. Questionnaires were distributed and interviews were done to find out local community perceptions toward the implementation and the incentives of tourism development plans in Tomohon. The respondents consisted of the government staff in district and village office, the staff at Tourism Department in Tomohon, the local people around Linow Lake, and tourists visiting the lake. There were 100 respondents filling in questionnaires in total. Several key informants were then chosen to be interviewed as to gain deeper data on perceptions and incentive performance in relation to the development of Linow Lake as a tourism object.

Gap analysis was made by comparing the incentive policy established by the government with the perceptions of the local people. The gaps analyzed were then discussed by referring to theories and results of previous studies by still considering the typology of the town and aspects in the management of the town of Tomohon.

\section{RESULT AND DisCUSSION}

\subsection{Tourism in Linow Lake}

Linow Lake is a volcanic lake which is related to geological process in Tomohon area as a volcanic area. The water of lake contains sulfur. Visiting volcanoes and other geothermal phenomena is becoming more popular. The popularity of the area, i.e. geological feature, is often becomes the key for the economic growth in the regions around tourism objects [10] [11].

Located in mountainous area, the beautiful scenery around the lake and the preserved environment, mostly dominated by hills and mountains, supports the tourism development program. The existence of the green area on altitude above $700 \mathrm{~m}$ contributed to the formation of cool and fresh micro climate, creating relaxing environment. In many parts of Indonesia, lakes located in this kind of place have grown into attractive tourism objects able to develop economy and wealth of the local community and the region.

On the areas surrounding the lake, the geological phenomenon of volcanic zone has caused some cracks on the ground, spouting hot boiling water and white smoke containing sulfur. There are no plants found in areas around the lake which are directly affected by the sulfur. Plants grow on areas where sulfur is not present. On those areas, many kinds of trees, bushes, and herbs grow. Sometimes, grouses are found in the lake. 
Certain kinds of bugs, local people call them as sayok and komo, are also found around the lake. Linow Lake is the important habitat for Tomohon's biodiversity.

Local government has provided and built a path around the lake for people to enjoy the beauty of the lake closely. The central bursts of sulfur are not open for tourists regarding safety concern. Tourism spots are opened in areas which free from sulfur smoke to guarantee the safety of tourists. Safety is the most important aspect to consider in tourism. This means that tourists must not be put into risks of visiting dangerous areas [12]. Some other infrastructure supporting tourism in Linow Lake is wooden bridges facing the lake, cottages, toilets, restaurants, playgrounds, and parking lots. Technically, the infrastructure and facilities provided are good enough and fulfill the standard for quality infrastructure and facilities in tourism areas [13].

According to the administrators of the lake, most of the tourists visiting to the lake are from Asia, such as Japan, Korea, China, and Singapore. This is not so much different with the national data on the trend of tourist origins coming to Indonesia [14].

\subsection{Tomohon tourism policy}

Policy on tourism development in Tomohon is an integral part of the North Sulawesi development plans to become a world class tourism destination. North Sulawesi is very rich in natural resources and culture which can be used as the main tourism attractions. North Sulawesi has long been famous with its undersea tourism at Bunaken Island [15]. The policy related to tourism development in Tomohon is written in the government documents such as Medium-Term Development Plan and Government Work Plan Year. Some basic aspects affecting the development of tourism in Tomohon are consideration on the harmony between the vision of the North Sulawesi government that is making North Sulawesi a world class tourism destination and the trend of tourism growth in Tomohon. The data on the number of tourists coming to Tomohon shows an increase, as much as $22 \%$ in 2010 , and the number of domestic tourists increases as much as $93 \%$ [14].

The priority of tourism development in Tomohon in 2013 is on the optimization of support from other sectors in the preparation of Tomohon in to a quality tourism object. Priority is also given to the effort of improving investment on tourism sector, optimization of information and communication technologies (ICTs) advancement as a promotional medium, and improving the quality and quantity as well as professionalism of human resources. Innovations by the local government are part of the efforts to improve tourism performance in Tomohon. An area which is designed to attract investors and visitors must provide sufficient facilities and infrastructure [16].

In the context of planning system, there are three main important issues to realize Tomohon as a tourism destination (Figure 1).

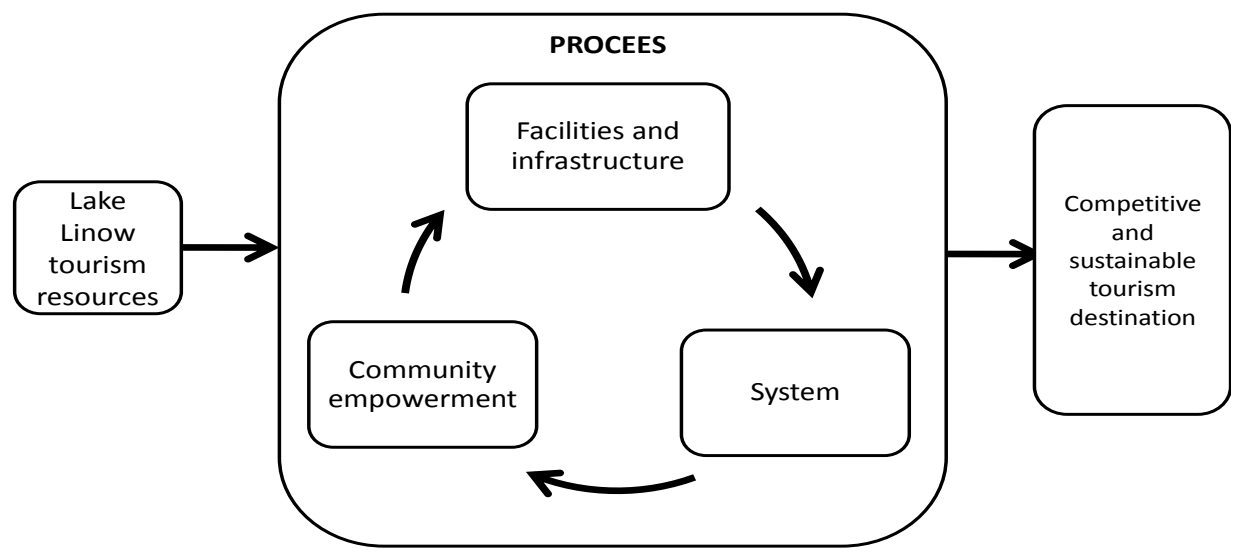

Figure 1. Three aspects in the realization of Tomohon towards competitive and sustainable tourism destination

The results of document analyses show that there are three main aspects in the development of tourism in Tomohon, namely provision and improvement of tourism facilities and infrastructure, provision of good information system and network to support the execution of tourism development policy, and local community reinforcement. The three aspects are explained as follows:

\section{Facilities and Infrastructure}

Road is the main component in tourism. Based on the data, the quality of roads in Tomohon shows important improvement. In 2006, the quality road was $121.85 \mathrm{~km}$ and in 2010, it was $225.34 \mathrm{~km}$. Paved road increases in length, while dirt road decreases in length [17]. However, there is fluctuation in the length of gravel road (Table 1) 
Table 1. The length of roads in Tomohon according to the kinds of road surface $(\mathrm{km})$ Year $2006-2010$

\begin{tabular}{lrrrrr}
\hline Kinds of Surface & \multicolumn{1}{c}{2006} & \multicolumn{1}{c}{2007} & \multicolumn{1}{c}{2008} & \multicolumn{1}{c}{2009} & \multicolumn{1}{c}{2010} \\
\hline Paved road & 190.37 & 206.64 & 231.90 & 262.02 & 264.34 \\
Gravel road & 40.12 & 47.77 & 32.25 & 23.23 & 44.22 \\
Dirt road/path & 84.37 & 65.45 & 68.95 & 56.65 & 64.02 \\
\hline \multicolumn{1}{c}{ Total } & 314.86 & 319.86 & 333.10 & 341.90 & 372.58 \\
\hline
\end{tabular}

(Sources: Tomohon in Figures in 2011)

\section{Improvement on Promotion System:}

Development on promotion system can be done by improving database and information system related to tourism, conducting integrated promotion through Trade, Tourism and Investment (TTI), providing communicative websites to attract tourists, and developing quality and continuous network and relations. The promotion of tourism in Tomohon is actively done through national and international events such as Tomohon Flower Festival [18].

\section{Local Community Empowerment:}

The government of Tomohon is trying improving local community awareness and involvement in tourism development through many ways, such as providing fund for creative small-scale industries in tourism. Culture and local arts are the things to which government pays a lot of attention. Reinforcement must be given through trainings for artists and people involved in art and culture preservation.

Empowering local people in terms of arts and culture is crucial; and this can be seen from the fund allocated for tourism development in Tomohon [18]. One of the aspects to put culture as a priority in tourism development is the concern on Minahasa culture preservation.

With these three considerations, it is expected that Tomohon grow into a competitive and quality tourism destination based on local power and abilities. According to the tourism official document statement, this approach is particularly useful towards sustainable and competitive tourism destination. These aspects are believed as a foundation of future tourism development in Linow Lake.

\subsection{Public responses toward the incentive system in tourism development}

The local people around the lake understand that Linow Lake is being developed as one of the natural tourism object in Tomohon. The people also state that developing Linow Lake into a competitive tourism destination is important. They think that the local government needs to carry out efforts to preserve the lake and to make policy suitable with the purpose of developing Linow Lake into a competitive tourism destination. According to respondents, roads become such absolute need for tourism. As an example, the road from the gate of the village into Linow Lake, as long as $700 \mathrm{~m}$, needs to be made wider to support tourist mobilization and to prevent accident.

Respondents stated that the main threat to the lake would be environment degradation. Thus, government needs to socialize the program of planting trees around the lake to the local people. To make it more effective, the government can establish regulations to prevent people from destroying the areas around the lake and damaging the lake itself. Many documents containing policy on tourism development in Tomohon, especially Linow Lake, are responded in different ways by the local people, as summarized in Table 1.

Table 2. The perceptions of the local people toward the incentive system to improve the quality of tourism at Linow Lake (Range of Scores from 1 (Completely Bad/disagree) - 5 (Completely Good/Agree).

\begin{tabular}{|c|c|c|}
\hline No. & Incentive System & $X$ \\
\hline 1 & $\begin{array}{l}\text { The concern of Tomohon government toward the improvement of facilities and } \\
\text { infrastructure at Linow Lake }\end{array}$ & 3,87 \\
\hline 2 & Trainings for the management staff of Linow Lake & 3,83 \\
\hline 3 & $\begin{array}{l}\text { Efforts to protect the lake from any kinds of cultivation which may harm the function } \\
\text { and preservation of the lake }\end{array}$ & 3,82 \\
\hline 4 & The concern of Tomohon government toward roads around Linow Lake & 3,77 \\
\hline 5 & The development of Linow Lake & 3,77 \\
\hline 6 & Physical development of Linow Lake & 3,68 \\
\hline 7 & $\begin{array}{l}\text { The promotion of Linow Lake as a tourism destinantion becomes more effective and } \\
\text { efficient compared to promotion of other tourism destinations }\end{array}$ & 3,68 \\
\hline 8 & Subsidi for the development of Linow Lake & 3,36 \\
\hline
\end{tabular}

Source: Data Processed 
From the table, it is clear that the local community can take advantages from the incentive program done by the government. The local people at least can feel the advantages from the socialization programs and trainings, as well as physical improvement. The government concerns in improving facilities and infrastructure, in developing human resources capability, and in preserving the ecosystem of the lake have gained such good appreciation from the local community. This means that the development of Linow Lake and its surrounding area as a tourism destination has fulfilled the aspects of sustainable development. Although maximum results have not yet been gained, the present strategies will lead Linow Lake to become a sustainable tourism destination and attraction. Experts state that in order to realize a sustainable, competitive, and attractive tourism destination, equality of economic, social, and environmental aspects is obviously important [19] [20].

The government of Tomohon allocated quite big fund for their tourism sector development in 2012. It is encompasses marketing development program (3.6 billions), destination development program (646 million), and networking development program (140 millions) [18]. The fund allocated for marketing is so huge, that is $83 \%$ from the total fund allocated for tourism sector development. However, the people of Tomohon think that their government needs to allocate bigger amount of fund in the future.

\subsection{Perception Toward the Quality of Tourism Management at Linow Lake}

The perceptions of the local people related to the quality of tourism management at Linow Lake are summarized in Table 3. From the table, the local people see the managerial function of the local government in building coordination and capacity improvement as good. Trainings for those in charge of tourism objects management around Tomohon can help to improve their performance.

Problem on the incentive system appears related to the direct effects experienced by the local people. The local people think that the economic impacts of the tourism development are not sufficient. Professionalism in the management of the lake also needs improvement. The concept of sustainable tourism is grasped in the mind of the people, yet its implementation needs some more revision.

Table 3. Local Community Perception on The Management of Linow Lake as a Tourism Object (Range of Scores from 1 (Completely Bad/disagree) - 5 (Completely Good/Agree).

\begin{tabular}{|c|c|c|}
\hline No. & Quality Aspects & $X$ \\
\hline 1 & Coordination of management functions among each sector to develop Linow Lake & 4.07 \\
\hline 2 & $\begin{array}{l}\text { Continuous training and education on tourism by the local government for local } \\
\text { community }\end{array}$ & 3.99 \\
\hline 3 & Responsibility of Linow Lake managements to preservation of the lake & 3.98 \\
\hline 4 & Beauty and uniqueness of Linow Lake as one of its major attractions & 3.81 \\
\hline 5 & $\begin{array}{l}\text { Accommodation and restaurants available around the lake affects the lives of the local } \\
\text { people around the lake }\end{array}$ & 3.80 \\
\hline 6 & Behavior patterns and improvement of local community welfare & 3.75 \\
\hline 7 & $\begin{array}{l}\text { Government concern on the improvement of the welfare of the people in the management } \\
\text { board of Linow Lake }\end{array}$ & 3.74 \\
\hline 8 & Linow Lake as a tourism object has been managed professionally & 2.98 \\
\hline
\end{tabular}

Sumber: Data Processed

\subsection{Gap in The Tourism Development}

Related to policy in the development of sustainable tourism site, it seems that the local government is trying completing all the aspects required by that particular approach of sustainable tourism. The incentive system developed is also projected toward creating sustainable tourism, in which the development of tourism will not only increase the local government revenue, but also contribute to nature conservation and culture preservation for those living around the lake.

The incentive system developed is also made in line with the goal of sustainable tourism, in which the growth of tourism sector will not only increase government revenue, but also contribute to the culture of Minahasa and to the conservation of the environment around the lake. The incentive system designed by the local government is not optimal yet for some factors, such as policy related problems and weaknesses, the low capacity of human resources, imbalance fund allocation, and some other factors. There is not any comprehensive system and policy related to the management of tourism at Linow Lake. There is not any regulation established by the local government which can be a legal foundation for the lake to be an acknowledged tourism site and the ticket rate. Scholar point out that involving all stakeholders is very important [21].

Low human resources capacity, both the government staff and the local people, is the cause for low community participation [22] [23]. These people need to be introduced to skills and technology used in tourism management. Thus, the local government of Tomohon needs to hold trainings to teach their staff and local 
community the skills and technology needed. This is mainly relevant since the role of information technology has become so dominant to win market competition these days.

Physical development in the tourism area has been done, yet lack of facilities and infrastructure still exists, especially those needed to guarantee the comfort and safety of the tourists. Those in charge of tourism management in this area can develop the basic infrastructure, such as opening up paths, shelters, security posts, as well as putting signs to warn and guide tourists on the way

\section{CONCLUSION}

Lake Linow is one of the natural tourism attractions in Tomohon which is potential to be developed further. The local government of Tomohon has implemented an incentive system to support the sustainable development of the lake so that it can produce higher revenue for the government and improve the welfare of the local people. The system is running well, yet its quality still needs revision and improvement. The local people think that non-physical aspects, such as management, need to be managed more professionally. In addition, intensive training and education related to the management of tourism objects must be done continuously.

\section{Acknowledgements}

Authors would like to thank Prof. Soemarno and Dr. Lantemona for support and academic advice. The research was fully funded by Ministry of National Education Republic of Indonesia (BPPS).

\section{REFERENCES}

[1] A. Singh, Asia Pacific tourism industry: Current trends and future outlook. Asia Pacific Journal of Tourism Research, 2(1), 1997, $89-99$.

[2] L. Hakim, J. E. Kim, and S. K. Hong, Cultural landscape and ecotourism in Bali Island, Indonesia. Journal of Ecology and Field Biology 32(1), 2009, 1 - 8 .

[3] M.J. Walpole and H.J. Goodwin, Local economic impact of Dragon tourism in Indonesia. Annals of Tourism Research, 27, 2000, 559 $-576$.

[4] R. Sharpley and D.J. Telfer, Tourism and development: Concepts and issues, (Multilingual Matters, 2002).

[5] C.M. Hall and S. Page, Tourism in South and Southeast Asia. (Routledge, 2012).

[6] T. Berno and K. Bricker. Sustainable tourism development: The long road from theory to practices. International Journal of Economic Development 3(3), 2001, 1 - 18.

[7] Law of the Republic of Indonesia Number 24 of 1992 on Spatial Planning, Jakarta Indonesia.

[8] B. Prideaux, The resort development spectrum: A new approach to modeling resort development. Tourism Management, 21(3), $2000,225-240$.

[9] J. Khadaroo and B. Seetanah, Transport infrastructure and tourism development. Annals of Tourism Research, 34(4), 2007, 1021 1032 .

[10] T.W. Heggie, Geotourism and Volcanoes: Health hazards facing tourists at volcanic and geothermal destinations. Travel Medicine and Infectious Disease, 7(5), 2009, $257-261$.

[11] L. Hakim, L. Cultural Landscapes of the Tengger Highland, East Java. In: S. K. Hong, et al. (eds.) Landscape Ecology in Asian Cultures. (Ecological Research Monographs, Part I, pp: 69-82, Springer Verlag, Tokyo, 2011).

[12] A.L. Hansell, C.J. Horwell, and C. Oppenheimer, The health hazards of volcanoes and geothermal areas. Occupational and Environmental Medicine, 63(2), 2006, 149 - 156.

[13] M. Baud-Bovy and F. Lowson, Tourism and Recreation: A Handbook of Planning and Design (Architectural Press, Oxford, 2002).

[14] Central Bureau of Statistics, Indonesian Tourism Statistics (Ministry of Tourism and Creative Economy, Jakarta, 2011).

[15] L. Hakim, Soemarno, S.K. Hong, Challenges for conserving biodiversity and developing sustainable island tourism in North Sulawesi Province, Indonesia. Journal of Ecology and Field Biology. 35(2), 2012, 61 - 71.

[16] P. Kotler, D.H. Raider and I. Rein, Marketing Places: Attracting Investment, Industry and Tourism to Cities, States and Nations (The Free Press, New York 1993).

[17] Tomohon in Figure, Tourism Statistics Tomohon (Office of Statistics, City of Tomohon, North Sulawesi, Tomohon 2011).

[18] Office of Tourism Tomohon, Determination of Performance and Budget of Tourism in Tomohon City (Office of Tourism Tomohon, North Sulawesi 2012).

[19] R. Sharpley, R. Tourism and sustainable development: Exploring the theoretical divide. Journal of Sustainable Tourism, 8(1), 2000, $1-19$.

[20] Z. Liu, Sustainable tourism development: A critique. Journal of Sustainable Tourism, 11 (6), 2003,459 - 475.

[21] O. Krutwaysho and B. Bramwell, Tourism policy implementation and society. Annals of Tourism Research, 37(3), 2010, 670 691.

[22] C. Tosun, Limits to community participation in the tourism development process in developing countries, Tourism Management, 21(6), 2000, $613-633$.

[23] T. Baum, Human resources in tourism: still waiting for change. Tourism Management 28(6), 2007,1383 - 1399. 